\title{
Perceived Brand Equity in Professional Sports Teams: A Zimbabwean Consumers' Perspective
}

\author{
Lysias Tapiwanashe Charumbira* \\ Graduate School of Business, National University of Science and Technology, Bulawayo, ZIMBABWE \\ *E-mail for correspondence: lysiastapiwacharumbira1968@gmail.com
}

\begin{abstract}
The study explored the antecedents, dimensions and market consequences of the brand perceptions held by Zimbabwean consumers for professional football teams and developed a strategic brand management framework that can bridge existing practical and theoretical knowledge gaps in the management of sports brands in the country. The study was grounded on the exploratory sequential mixed methods research design. In the qualitative strand of the study, data was collected by means of such qualitative data collection procedures as, free-thought listing, semi-structured interviews and focus group discussions. The findings from the qualitative phase were used to generate data collection instruments for questionnaire survey and assess the overall prevalence of the variables that were identified in the first phase from a large number of users of football brands. The NVivo 10 and SPSS version 21.0 software packages were used to analyze qualitative and quantitative data, respectively. The study identified and classified the antecedents of brand perceptions held by Zimbabwean consumers for professional sports teams into consumption experience-trigged antecedents, significant others-triggered antecedents and sports entity-triggered antecedents. The results show that fan loyalty trends for local professional football teams function in tandem with the ethnic identity systems in the country. However, the globalization of football has led to the dilution of national particularities in the game. The findings support the conceptualization of perceived brand equity in as an aggregate of brand awareness and brand associations. Zimbabwean consumers of football brands perceived European professional football teams as the market leaders in their brand category. South African professional football teams were ranked second and Zimbabwean professional football teams were positioned at the bottom of the brand leadership rankings in the minds of Zimbabwean consumers of football brands. The study illustrated how the brand the perceptions held by Zimbabwean corporate and individual consumers for professional football teams have generated negative and positive market consequences.
\end{abstract}

Keywords: Perceived Brand Equity, Brand Awareness, Brand Associations, Antecedents of Brand Equity, Brand Equity Dimensions, Market Consequences

\section{INTRODUCTION}

Dall'Olmo Riley (2009) notes that the definition of the brand construct remains one of the unresolved issues in brand management literature. There is wide disagreement amongst scholars on the subject .Since there is no universally accepted definition of the brand construct, this paper conceptualizes a brand as the totality of how an organisation and its products or services are perceived by current and prospective customers.

In the same vein, Dall'Olmo Riley (2009) view brand equity as the second contentious area in branding literature.This is corroborated by Winters (1991, p.70) who argues that "if you ask ten people to define brand equity, you are likely to get ten (maybe 11) different answers as to what it means".

Keller (2008) notes that although there is no universally accepted definition of brand equity, all the definitions share the notion that brand equity denoted added value endowed by the brand to the product, and it can be positive or negative. This is captured by Kotler and
Pfoertsch (2006) who argue that the concept of brand equity is generally meant to capture the value of a brand. This paper views perceived brand equity as an aggregate of the how well consumers are aware of the sports entities (Identification) and the depth of the psychological connections that customers have with those sports entities (Internalization), on the one hand, and totality of the strength, favourability and uniqueness of the brand associations (image) that the sports entities own inside the minds of consumers, on the other, and it can be positive and negative.

The study was inspired by Kerr and Gladden (2008) who encouraged future research in order to identify factors that might contribute to the creation of professionalsport team brand equity. Higgins (2006) adds to this view where she argues that understanding how brand equity can lead to competitive advantage is essential for sports managers because sport naturally has an uncertain outcome, and they cannot control wins or losses. 
Although research on sport brand equity has received increased attention from scholars in the last twenty years, the nature and significance of sport branding is opaque and remains under researched. This is captured by Ross (2006) who argues that although sports organizations have begun to realize the benefits of creating favourable brand associations, very few studies in branding literature have approached brand equity from a sport perspective. Most frameworks on sports team brand equity do not take into account the subjective, intangible and experiential nature of sport, since they were developed from a manufactured goods perspective (Ross, 2006). It was also noted that some of the frameworks on brand equity in sports teams do not accurately mirror the brand associations of sports teams, since they were developed from brand association dimensions developed by the researchers as opposed to customer brand perceptions (Ross, James and Vargas (2006).

Biscaia et al. (2013) note the dimensionality of brand equity professional sports teams has not been unanimous. The sports brand equity models by Gladden et al.(1998),Gladden and Milne (1999) and Kerr and Gladden (2008) are based on Aaker's (1991) Brand Equity model and they conceptualise brand equity as an aggregate of brand awareness, perceived quality, brand associations and brand loyalty .On the other hand, the sports brand equity models by Gladden and Funk (2002),Bauer, Sauer and Schmit (2005), Bauer, Stokburger-Sauer and Exler (2008) and Arai, Ko and Kaplanidou (2013) are grounded on Keller's(1993) Brand Knowledge model and they conceptualise brand equity as an aggregate of brand awareness and brand associations. In the same vein, although the models by Ross (2006), Ross et al. (2006), and Naik and Gupta (2013) were not developed from a manufactured goods perspective, they also conceptualise sport brand equity as an aggregate of brand awareness and brand associations. Some of frameworks on sport branding only focus on a single dimension of brand equity (brand associations).

Since building strong brands is about developing and maintaining strong perceptions in the minds of customers (Kotler and Phoertsch, 2006), the study sought to explore the antecedents, dimensions and market consequences of the brand perceptions held by Zimbabwean users of professional brand and develop a strategic brand management framework that can bridge existing practical and theoretical knowledge gaps in the management of sports brands in the country.

\section{MetHodology}

The study followed the exploratory sequential mixed methods research design, as described by Creswell and Plano Clark (2011),in that it utilised such qualitative procedures as; free-thought listing, semi-structured interviews and focus group discussions to explore the antecedents, dimensions and market consequences of the brand perceptions held by Zimbabwean consumers for professional football teams in its first phase. In the qualitative phase of the study. Semi-structured interviews were used to collect data from five categories of producers and users of football brands, with samples being purposively selected from each stratum for detailed investigation, as summarized in Table 1 below.

Table 1: Sample Size for Semi-Structured Interviews

\begin{tabular}{|l|c|}
\hline Strata & $\begin{array}{c}\text { Numbers of } \\
\text { Samples Included } \\
\text { in the Study }\end{array}$ \\
\hline 1.Individual consumers of football brands & $\mathrm{N}=41$ \\
\hline 2.Corporate Consumers of football brands & \\
\hline a)Sponsors & $\mathrm{N}=8$ \\
\hline b)Sports Reporters & $\mathrm{N}=7$ \\
\hline c) Broadcasters & $\mathrm{N}=2$ \\
\hline $\begin{array}{l}\text { 3.Producers of football } \\
\text { brands(Professional football teams) }\end{array}$ & $\mathrm{N}=6$ \\
\hline Total & $\mathrm{N}=\mathbf{6 4}$ \\
\hline
\end{tabular}

The sample of 64 interviewees was considered adequate to achieve data saturation, theoretical saturation, or informational redundancy since it is much greater than the minimum threshold of 12 participants, as recommended by Guest, Bunce and Johnson (2006).

The Free-thought listing technique was used to identify the brand associations that consumers hold toward their favourite professional football team. The Free-thoughtlisting process was used to collect data from sixty nine purposively sampled fans of professional football teams. Three focus group discussions were carried out to further explore the themes that emerged from the semistructured interviews. The decision to conduct three focus group discussions, on the other hand, was informed by the recommendations from Onwuegbuzie et al. (2009) who argue that 3-6 focus groups can generate adequate information to meet the exploratory objectives of most qualitative studies.

In the second phase of the study, the findings from the qualitative strand were used to generate data collection instruments for questionnaire survey. This was meant to assess the overall prevalence of the variables identified in the first phase from a large number of users of football brands. Structured observation was also used to gather data in this phase.

For the purpose of the questionnaire survey 600 questionnaires were distributed, of which 465 were completed and returned. The main section of the questionnaire contained questions where all items were measured on a 7-point Likert type scale; ranging from Strongly Disagree to Strongly Agree. Neuman (2004) notes that, using such a scale for large numbers of questions, as was the case in this study can result in a "response set"- a situation where respondents display a tendency for answering questions in the same way, out of laziness or a psychological predisposition. To minimize this effect, the completed questionnaires were thoroughly scrutinized 
and those that were not fully completed or contained 10 or more consecutive answers on the same scale were excluded from the final analysis, leaving 402 usable questionnaires, for an effective response rate of $67 \%$.

Structured street observation surveys were used to determine the market consequences of the brand perceptions held by Zimbabwean consumers for professional football teams, by measuring Zimbabwean football fans' "active engagement levels" with local, regional and global professional football brands.This was done by comparing the frequency with which fans in Bulawayo ,Harare and Mutare wear clothing that features the logos of local, regional and global professional football teams during selected days when there were no matches involving any of the teams that are popular on the Zimbabwean football market. A total of 2085 cases of fans wearing replica jerseys of professional football teams were observed.

In this study, the NVivo 10 software package was used to analyse qualitative data. The analysis of quantitative data was performed using the Statistical Package for Social Sciences (SPSS) version 21.0 data analysis software. Data analysis was connected, and integration occurred at the data interpretation stage

\section{RESULTS}

The findings from the qualitative strand of the study identified family influence, peer pressure, ethnicity, coproduct related attributes and the benefits attached to sport consumption as the main reasons why some Zimbabwean consumers support local professional football teams. The results show that fan loyalty trends for local professional football teams function in tandem with the ethnic identity systems in the country.

The mass exodus of Zimbabwean footballers to South African teams has influenced some Zimbabwean fans to follow and become attached to South African professional football teams. In the same vein, the marketing strategies of such English professional football teams as; Arsenal Football Club, Chelsea Football Club, Liverpool Football Club, Manchester City Football Club and Coventry Football Club involving the recruitment talented footballers from Zimbabwe and other African countries influenced Zimbabwean fans to support these teams. These findings partly corroborate the views of (Wann et al., 1996) who note that the initial reasons for becoming a fan are parental and family influence, the players' talent level and personalities, geographic and peer influence, and the team's success. They also capture the observations by Chanavat and Bodet (2009) who note that geographic, cultural and family bonds were the strongest antecedents of brand equity in European professional football teams.

The antecedents of brand equity that were identified in the qualitative strand of the study were incorporated in the questionnaires that were used to collect data from 402 individual consumers of football products in order to test their prevalence in wider population. A One- sample T-test $(\alpha=0.05)$ with a test value of 4.0, indicating the midpoint of a 7-point Likert-type scale, was used to validate the listed antecedents of brand equity for local and foreign professional football teams.

- Any mean scores that were greater than the test value (4.0), indicated that the factor under consideration was a significant antecedent of brand equity in professional football teams.

- Any mean scores that were less than the test value (4.0), indicated that the factor under consideration was an insignificant antecedent of brand equity in professional football teams.

- Mean values equal to the test value (4.0), indicated that the factor under consideration is neither significant nor insignificant as an antecedent of brand equity in professional football teams.

The findings identify Star Player $(M=6.64)$,Team play characteristics $(M=6.53)$, Team success $(M=6.44)$,Escape $(\mathrm{M}=6.37)$,Media influence $(\mathrm{M}=6.36)$, Social Interaction $(\mathrm{M}=6.22)$, Head coach $(\mathrm{M}=5.93)$,Rivalry $(\mathrm{M}=5.86)$, Team heritage $(M=5.86)$,Brand image $(M=5.65)$, and Organizational commitment $(\mathrm{M}=5.21)$ as the most significant determinants of brand equity in professional football teams on the Zimbabwean Market.

However, mean values below the test value (4.0) were recorded for such factors as; Ethnic and geographical considerations $(\mathrm{M}=3.88)$, Security and Stadium factors ( $\mathrm{M}$ $=3.73)$, Concessions $(M=3.50)$, Service quality $(M=3.06)$ and Business opportunities $(\mathrm{M}=2.80)$. This is because these factors do not apply across all sport settings.

These findings are in line with the views of Wright (1999) who argued that the globalization of football has led to the dilution of national particularities in the game.

On the antecedents of brand equity in consumer-team relationships involving corporate consumers, the results showed that the companies' football selections decisions for sponsorship and media coverage are mainly influenced by the football entity's perceived brand equity, since it determines return on investment.

According to these findings, perceived brand equity in professional football teams on the Zimbabwean market is determined by the amount of information that customers have about the teams and the strength and favorability of the brand associations (images) that the teams own inside the minds of consumers. The study identified several factors, which lead to the creation of brand equity in professional football teams. These factors were then grouped into three categories by clustering related elements together.

The first category was coined as, Consumption ExperienceTrigged Antecedents. This category represents the experienceinduced brand perceptions that sports consumers develop as they consume the core-product of their favorite sports teams through one or a combination of the various modes of sport consumption, such modes of game consumption as; live attendance at the match venue, television, radio, newspaper, social networks and the internet. 
The second category was coined as, Significant OthersTriggered Antecedents, which includes the brand perceptions that sports consumer develop as a result of the actions or attitudes of individuals or organizations they admire or respect towards the sports team. This may include, but is not limited to the team brand perceptions that customers develop as a result of the actions or attitudes of the media, corporate sponsors, family members, peers, celebrities, stock price movements and other influential people in society towards the sport or team. This may also include the actions of other fans who promote their favorite sports brands indirectly by wearing and displaying licensed team merchandise.

The third group of antecedents was coined Sports EntityTriggered Antecedents. It represents the brand perceptions that are generated by the sports team's deliberate marketing mix management efforts. They include situations where sports teams use one or various combinations of such marketing mix elements as the; product, place, price ,promotion, process, people and physical evidence to generate brand awareness or influence customers to develop favorable and differentiated team brand associations.

\section{The dimensions of sports team brand equity The dimensions of brand equity}

Biscaia et al. (2013) note the dimensionality of brand equity in professional sports teams has not been unanimous. In line with the views of Keller (1993), Erdem and Swait (2004), and Ross (2006), the research findings do not support Aaker's (1991) conceptualisation of brand equity as an aggregate of brand awareness, perceived quality, brand associations and brand loyalty . The findings from the free-thought listing survey view brand loyalty as a consequence of brand of brand equity and perceived quality as part of product-related brand associations. As a result, perceived brand equity in professional football teams is an aggregate of brand awareness and brand associations and this can be negative or positive.

\section{Brand Awareness}

The findings corroborate the observations by Ross et al. (2008), who view Team Identification and Internalization as antecedents to sport team awareness.

On team identification, results showed that respondents had good levels of awareness for their favorite professional football teams since they were able to accurately recall their brand attributes. The participants had better levels of brand awareness for foreign professional football teams than local professional football teams. In the free-thought listing survey, only $27.3 \%$ of the teams that were listed by the 69 participants as their favorite professional football teams were local and $72.7 \%$ were foreign. The results from semistructured interviews with 41 individual consumers of football products showed top-level awareness for 24 professional football teams, of which $29.2 \%$ were Zimbabwean and $70.8 \%$ were foreign. Focus group discussions yielded similar results by showing top level awareness for 12 professional football teams, of which, $33.3 \%$ were Zimbabwean and $66.7 \%$ were foreign. The media-based consumers also showed top-level awareness for 3 local teams (27.3\%) and 8 foreign teams $(72.7 \%)$.These trends closely mirror the extensive exposure that foreign professional football teams receive on the television stations that are popular with Zimbabwean users of football brands. The findings highlight the need for Zimbabwean professional football teams to adopt media and marketing communicationbased brand building strategies in order to increase the levels of brand awareness among local consumers.

The findings relating to internalization showed that the fans were strongly psychologically committed with theirfavourite professional football teams.

Free-though listing and interview participants illustrate the depth of their emotional connections with the teams through statements like:

- "Would support it even if it's relegated".

- "A team worth dying for".

- "My social life revolves around this football team",

- "I see the team as part of my family".

- "My social and emotional connections with the teams are very deep because I get stressed when the team loses".

- "The team makes me feel happy when it wins and it instills a sense of community and regional pride in me".

- "The team makes me feel happy, proud and socially accepted".

The majority of the individual consumer interviewees indicated that they "frequently or always" think about their favorite professional. They also acknowledged that they had deep emotional connections with other fans of their favourite professional football teams. To buttress this point, one of them said,

- "Yes, we meet frequently to share our successes and misery".

Most of these participants indicated that they follow "almost every game" played by their favorite teams and "frequently" visit the team's official websites and social network pages. They also indicated that they frequently buy and regularly display merchandise belonging to their favorite professional football teams.

$85.3 \%$ of the individual consumer interview participants indicated that they have never changed the football teams they support. $95.1 \%$ of these interviewees indicated that they would not switch their support to other teams if their favorite teams start performing badly on the field of play. In the same vein, $73.8 \%$ of these participants indicated that they would not switch their support to other teams if their favorite teams conduct themselves in a manner that tarnishes their public images or destroys their credibility since every institution has a bad spell at some point and 
mistakes can always be corrected. These findings concur with those from a study by Neal (2006) which established that sports teams seem to gather uncommon levels of loyalty from their customers. As a result, they can weather economic downturns, long-term competitive disadvantage and continual performance failures on the field of play, to emerge with a core of dedicated, committed and loyal customers (Ibid). However, the participants agreed that "star struck fans", whose allegiance to a team is influenced by the presence of their favorite player at the team tend to switch their loyalty when the star player moves to another team or retires from the game. To sum up this thinking one of the participants had this to say:

"At one point, I was a staunch FC Barcelona supporter. My support for that team was influenced by the presence of my favorite player at that time, Louis Figo, at the Club. When Figo moved from FC Barcelona to Real Madrid, Iswitched my allegiance to Real Madrid. By the same token, the presence of Christiano Ronaldo at Manchester United influenced me to support that team and I switched my loyalty to Real Madrid Football Club when he transferred from Manchester United Football Club to the Spanish Giants".

Participants also felt that those fans whose loyalty to professional football teams was influenced by the actions of such third party sources as their peers and family members, without having a firsthand experience with the team, are likely to shift their allegiance to other teams the moment they get first hand exposure to the team or competing brands. One of the participants illustrated this view by saying:

"I grew up in Mutare where I was influenced by one of my friends at school to support Highlanders

Football Club. When I relocated to Bulawayo, I went to the Babourfields Stadium to watch my favorite team play Dynamos Football Club in a league match. To my surprise, I was physically and verbally abused by my fellow Highlanders supporters who felt that it was improper for a non-Ndebele speaking fan to support Highlanders and this forced me to switch my loyalty to Dynamos Football Club".

The findings from the questionnaire survey in the quantitative strand of the study validated the fact that Zimbabwean consumers of football products were strongly psychologically committed with their favorite professional football teams.

A One-Sample T-test $(\alpha=0.05)$ with a test value of 4.0 , indicating the midpoint of a7-point Likert-type scale, was used to validate the Team Identification-related brand attributes identified in the qualitative strand of the study , as summarised in Table 2 below.

All the mean scores were greater than the test value (4.0), indicating that the study participants were strongly psychologically committed with their favorite professional football teams.

Table 2: Validation of Team Internalization

One-Sample Statistics

\begin{tabular}{|c|c|c|c|c|}
\hline & $\mathrm{N}$ & Mean & $\begin{array}{l}\text { Std. } \\
\text { Deviation }\end{array}$ & $\begin{array}{l}\text { Std. Error } \\
\text { Mean }\end{array}$ \\
\hline I always buy, display or wear my favourite team's merchandise. & 402 & 5.54 & 1.677 & .084 \\
\hline $\begin{array}{l}\text { I follow every game the team plays live on the field of } \\
\text { play/television/radio/website/social network page. }\end{array}$ & 402 & 6.62 & .800 & .040 \\
\hline I visit the team's website or social network page every day. & 402 & 4.49 & 2.138 & .107 \\
\hline I frequently think about this team. & 402 & 6.66 & .564 & .028 \\
\hline My psychological and emotional connections with the team are very deep. & 402 & 6.67 & .572 & .029 \\
\hline I feel a deep connection with others fans of this team. & 402 & 6.59 & .676 & .034 \\
\hline The team provides temporary escape from daily stress. & 402 & 6.99 & .157 & .008 \\
\hline I feel proud to be associated with this team. & 402 & 6.95 & .229 & .011 \\
\hline The team provides a vehicle of success with which consumers can affiliate. & 402 & 6.75 & 1.101 & .055 \\
\hline The team provides a vehicle for social approval and acceptance by peers. & 402 & 5.42 & 1.430 & .071 \\
\hline The team provides a common point for community, town or regional pride. & 402 & 6.31 & 1.393 & .069 \\
\hline $\begin{array}{l}\text { The team offers an opportunity and place to meet and spend time with friends and } \\
\text { other people. }\end{array}$ & 402 & 5.33 & 1.595 & .080 \\
\hline The team brings feelings of fun and excitement to its fans. & 402 & 5.64 & 1.489 & .074 \\
\hline
\end{tabular}

\section{Brand Associations}

The brand associations held by Zimbabwean consumers for professional football teams were profiled by means of free-thought listing survey and semi-structured interviews with individual and corporate consumers and validated through a quantitative questionnaire survey.
The study identified 16 brand associations' dimensions that were consistent with those in existing team sport brand equity literature.

These include; Brand Mark, Team Success, Rivalry, Team Tradition, Team Play Characteristics, Non-Player Personnel, Star, Player(s), Stadium/Venue Factors, Concessions, 
Commitment, Organizational Attributes, Management, Media Coverage, Sponsors/Owner, Social Interaction, Consumer Benefits and Regional Importance.

The study also identified 9 additional brand associations' constructs that have not been explicitly captured in existing team sport brand equity literature. The additional dimensions are ; Brand Leadership Status, Economic Success, Ethnic Considerations, Ethical Attributes, Security, Talent Identification and Development, Emotional Response, Corporate Social Responsibility and Team Benefits.

The 25 brand association dimensions that were generated qualitatively in the first phase of the study, were validated through a One-Sample T-test $(\alpha=0.05)$ in the quantitative strand of the study. The results show that such brand association dimensions as; ethnic and geographical considerations $(\mathrm{M}=3.88)$, security and stadium factors ( $\mathrm{M}$ =3. 73), concessions ( $\mathrm{M}=3.50)$, and service quality ( $\mathrm{M}$ =3.06) were insignificant associations, since they recorded mean values below the test value (4.0).

However, this does not mean that these elements should be deleted from the list of valid associations and neglected in future sport brand equity research. Their low mean scores stem from the fact that they do not apply across all the categories of the teams that were identified as favourites by the 402 respondents. For example, ethnic and geographical considerations recorded mean scores, above the test value (4.0), at $M=5.11$ and $M=4.08$ for South African and Zimbabwean teams, respectively, and their overall low mean score was a product of their limited applicability in European professional football settings. By the same token, the lower mean scores for stadium related factors can be attributed to the fact that the majority of Zimbabwean consumers consume the core-products of their favourite professional teams through the media. These findings are in line with the views of Wright (1999) who argued that the globalization of football has led to the dilution of national particularities in the game.

Data collected from individual consumers of football products show that they perceived local professional football teams as low value brands and European football teams as high value brands. These findings show that professional football teams have been able to generate positive brand associations along such brand dimensions as; team play characteristics, team success, organizational attributes, management, team tradition, non-player personnel, star player and brand mark and these mainly purported to European professional football teams. Negative associations mainly applied to Zimbabwean professional football teams. They included negative associations on product-related attributes where the respondents expressed their unhappiness with the inability to retain star players and quality technical personnel, poor current form, declining quality of football, poor team tactics. Along the management dimension, unfavourable associations included shambolic management practices and boardroom squabbles .Similarly, along the security and ethical dimensions, negative associations were recorded on such attributes as crowd violence, vulgarism, and bad behaviour by players. Finally, some of the respondents expressed their unhappiness with such ethnic discriminatory practices of some local professional football team as tribalism.

According to Ries and Ries (1998), a brand should use a colour that is the opposite of its major competitor. The participants noted that most top Zimbabwean and South African professional football teams live by this branding principle, since they use team colours that are different from those of their main rivalries. The findings, however, showed that in the English Premier League, teams have largely disregarded this branding principle. It was noted that:

- Arsenal FC, Liverpool FC and Manchester United share red as their main colour;

- Chelsea FC, Everton FC, Leicester City, Manchester City FC and Queens Park Rangers FC share blue as their main colour;

- Newcastle FC, Swansea City FC, Tottenham FC and West Bromwich Albion FC share black and white as their main colours;

- $\quad$ Stoke City FC, Southampton FC and Sunderland FC use almost identical red and white stripes;

- Aston Villa FC, Burnley FC and West Ham use more or less identical maroon stripes.

These findings were corroborated by the results from the One-way ANOVA Test, in the quantitative strand of the study where a Significance Value of .000 for the brand attributes:

The team's colours and logo are distinct from those of its main rivalries.

was less than the alpha (0.05).This shows that there were significant differences between the perceived attributes of Zimbabwean, European and South African professional along this brand attribute. European professional football teams score a relatively low mean score of $\mathrm{M}=4.32$ against $M=6.24$ and $M=6.23$, for Zimbabwean and South African professional football teams respectively. This validates results from the qualitative strand of the study which showed that the team colours and logos of European football teams were not as distinct from those of their main rivalries as those of Zimbabwean and South African professional football teams.

Semi-structured interviews with representatives of football sponsoring companies and media-based consumers of football brands showed that they hold more favourable brand associations for foreign professional football than local teams. The participants drawn from sports sponsoring companies emphasized that they prefer to associate their brands with football teams they perceive as brands of high value. This is in line with the views of Meenaghan (1983) who states that sponsors have to consider the event's opportunity for target audience coverage, as well as that firms have to be aware of the image of the event, the possible transfer of 
image from the event to the company and the risk for negative effect when being associated with an event.

The representatives of media-based consumers of football products attributed the failure by most top Zimbabwean professional football teams to attract positive and beneficial media coverage to their negative perceived brand equity.

The results from the qualitative strand of the study revealed that European professional football teams commanded better levels of brand awareness and have been able to generate more stronger and favorable brand associations in the mind of Zimbabwean corporate and individual users of football brands.

As a result, they are perceived as market leaders in their brand category by Zimbabwean consumers. South African professional football teams occupy the second position in the minds of the respondents who participated in the qualitative strand of the study. Zimbabwean professional football teams were positioned at the bottom of the standings.

In the quantitative, the One-way ANOVA Test was utilized to determine whether the perceived team brand attributes differed significantly between Zimbabwean, European and South Africa professional football teams.

European football brands recorded an average agreement mean score of 5.898 along the 40 brand attributes that were measures, South African brands followed closely with an average agreement mean score of 5.89225 and Zimbabwean brands were third with an average agreement mean score of 5.07575 .

This shows European professional football teams were perceived as brands of higher value when compared to South African and Zimbabwean professional football teams. South African professional football teams were also perceived as being superior in quality than Zimbabwean professional football teams.

\section{The consequences sports team brand equity}

The finding from the qualitative strand of the study showed that professional football teams derive a number of benefits from being perceived as having high brand value by individual and corporate consumers.

These benefits include; increased customer loyalty, improved media exposure, improved revenue flows from match tickets sales, improved revenue flows from corporate sponsorship, improved revenue flows from merchandise sales, improved revenue flows from broadcasting rights agreements, improved revenue flows from jersey rights agreements, improved revenue flows from stock market activities, free brand promotion by the media, sponsors and fans, and improved brand image. These consequences of brand equity were also validated with a wider population, in the quantitative strand of the study. The recorded high mean scores such consequences as; "the failure by Zimbabwean professional football teams to generate adequate revenue from Gate Revenue, Television Rights, Jersey Rights, Merchandise sales and
Corporate Sponsorship can be attributed to their low perceived brand value( $M=6.80)$ " and " European professional football teams' ability to generate adequate revenue from Gate Revenue, Television Rights, Jersey Rights, Merchandise Sales and Corporate Sponsorship to their high-perceived brand value (6.94)" show that the respondents strongly agreed with the classification of these factors as significant consequences of perceived brand equity in professional football teams.

\section{Conceptual Frameworks developed from the findings}

The results of the study were used to develop four sports brand equity conceptual frameworks and bridge existing practical and theoretical knowledge gaps in the management of sports brands in the country. These include:

The Sports Team Brand Hierarchy Conceptual Framework- which was proposed to address the lack of a brand hierarchy model, where teams from different countries are ranked in a single hierarchy according to the level of brand development. The framework can be used to determine the level of brand development and geographical sphere of influence of sports brands. It also provides guidelines on the growth strategies that teams, at the various levels of brand development can adopt for sustainable growth and competitive advantage.

The Integrative Framework for Assessing Perceived Brand Equity in Professional Sports Teams- which was proposed to address the fact that, there has not been a systematic study that examined and developed conceptual frameworks on brand equity in professional sports teams focusing on those sports fans who use more than one mode of consumption to consume sports products and those who use third party sources like the radio and newspapers as their mode of sports consumption. This framework seeks to increase knowledge on the antecedents, dimensionality and consequences of brand equity in professional sports teams and guide sport brand managers in their strategic brand building endeavours.

The Conceptual Framework for Understanding Sponsor Based Brand Equity in Professional Sports Teamswhich was proposed to address the lack of a systematic study that examined and developed a conceptual framework on brand equity in professional sports teams from a corporate sponsors' perspective. It seeks to guide sport brand managers on how to unlock sustainable revenues from these emerging revenue streams, for sustainable economic success and competitive advantage in intensely contested globalised markets. This framework shows the attributes that corporate sponsors consider when evaluating sports entities for sponsorship. As a result, it can help sports entities to appreciate and adapt to the attributes that sponsors consider when evaluating sports entities for sponsorship and improve their attractiveness to sponsors. 
The Conceptual Framework for Assessing Media-Based Brand Equity in Professional Sports Teams - which was proposed to address the lack of a systematic study that examined and developed a conceptual framework on brand equity in professional sports, teams from a media-based consumer's perspective. The framework seeks to help managers of professional sports teams understand what makes media practitioners perceive them in favourable way and adapt to those expectations by adopting appropriate brand-building strategies .It can also be used by media-based users of sports brands to evaluate and select sports entities for media coverage.

However, these frameworks will not be discussed in detail in this paper. They will be discussed in four separate papers which the author is currently working on.

\section{MANAGERIAL IMPLICATIONS OF THE STUDY}

The findings of this study allow a number of managerial implications to be derived for sustainable sports team brand management success.

The study suggests that although success on the field of play is one of the determinants of brand success in professional football teams, it leads to temporary marketplace outcomes. Sustainable marketplace success for professional football brands depends on their ability to increase customer awareness for their brands and generating strong, favourable and unique brand associations in the minds of current and prospective customers. It is against this background that, this study highlights the need for brand managers of professional teams to understand the sources of brand equity and how they affect market outcomes of interest such as media coverage, ticket sales, sponsorship, merchandise sales, broadcasting rights sales, jersey rights sales and stock market performance, as this can increase their ability to build strong brands and deliver them in a way that ensures sustainable market success.

There is also a need for managers of professional football teams to have sound knowledge on the dimensionality of brand equity, as this can improve the effectiveness of their brand building programmes through a better understanding of the elements strategy needs to focus on for successful brand equity enhancement.

The study highlighted the need for professional football teams to diversify and strengthen the teams' revenue bases by increasing inflows from television rights, merchandise sale, jersey rights, corporate sponsorship, advertising and stock market activities, for survival in modern football markets where inflows from traditional sources like gate revenue are declining.

As a result, it is critical for managers of professional football teams to increase knowledge on how to unlock sustainable revenues from these emerging revenue streams, for sustainable economic success and competitive advantage in intensely contested globalised markets.
For effective brand management, it is essential for managers of professional football teams to have a clear picture of the competitive positions occupied by their teams in the minds of customers, relative to competing brands and the brand strategies they need to adopt to improve the market competitiveness of their brands. This can be achieved through regular marketing research exercises focusing on how the various elements of brand awareness and brand associations are positioned in the minds of customers.

The findings show that in most professional football teams, sports sponsoring companies and media houses, the brand management function is handled by the marketing department. Therefore, there is need for these organizations to revolutionize their internal branding strategies and ensure that the brand is enhanced and protected at every point where the organization touches the customer. Future studies can also focus on conducting positivist studies based on representative samples to validate the conceptual frameworks that were proposed in this study to bridge the knowledge gaps that were identified in sports brand equity literature.

\section{LIMITATIONS OF THE STUDY}

The literature sources which provided a theoretical framework to the study were not written from a Zimbabwean perspective. Such literature may fail to accurately mirror the brand perceptions equity on the Zimbabwe sports market since they are based on studies that were carried out on organizations that operate under economic, political, socio-cultural and technological conditions which are different from those prevailing in the country. From a methodological point of view, the results from the qualitative strand of this study are based on small sample sizes. This raises questions about the representativeness of the data and how far it is justifiable to generalize from the findings. However, this was meant to gather in-depth information on the perceived brand equity of professional football teams on the Zimbabwean market and meet the exploratory purpose of the study.

Another key limitation of this study relates to the fact that it provides a view of a single sport, football. As a result, it cannot be generalized to other sporting disciplines. The decision to base the study on one sporting discipline was influenced by Onwuegbuzie and Collins (2007) who argue that if the goal is not to generalize to a population, but to obtain insights into a phenomenon, individuals, or events, as is the case with this study, then small samples can be used.

On the other hand, the findings from the quantitative strand may be too abstract and general for direct application complex business relationships associated with the brand perceptions held by consumers for professional football teams on Zimbabwean market. The researcher may also have missed out on valuable data because of the quantitative research's focus on causality and testing of conformity to the spectator-based brand equity models. 
The use of self-completed questionnaires in the quantitative strand of the study had a number of limitations that should be acknowledged. The survey covered the entire country and this made it impossible to have the researcher present as respondents completed the questionnaires. As a result, some respondents may have interpreted the meanings of questions or statements differently to those intended. The use of Likert-type scale instruments was meant to minimize problems associated with meanings. However, Neuman (2004) notes that, using such a scale for large numbers of questions, as was the case in this study can result in a "response set"- a situation where respondents display a tendency for answering questions in the same way, out of laziness or a psychological predisposition. To minimize this effect, the completed questionnaires were thoroughly scrutinized and those that displayed this tendency were not included in the final analysis.

The limitations of the qualitative and quantitative methods used in this study influenced the researcher to integrate these methods as a measure to strengthen the validity of the results. However, like all mixed methods research work, this study was labour and capital intensive, since it used multiple methods. It is also difficult for a single researcher to have expertise in both qualitative and quantitative methods, hence the researcher engaged research assistants with their associated high costs, to complement his efforts. In addition to this, mixed methods research approaches are a relatively new design and as such, some of the methodological details remain to be worked out fully by research methodologists.

Other limitations relate to the fact that this study is cross-sectional in nature .As a result; it cannot be relied upon to trace changes in the levels of customer loyalty to professional football teams over time.

Most of the individual participants in this study were students. Ideally, the participants should have been recruited from all the demographic segments of the Zimbabwean population by including a significant percentage of the employed and unemployed consumers of football brands to increase generalizability of the research findings. However, this limitation did not have much effect on the attainment of research objectives since students are often considered major consumers of sports products and frequently used in product and brand choice research since they are a captive and easily accessible audience (Biswas and Sherrell, 1993).

Trail, Fink and Anderson (2002) emphasize the need for researchers studying spectators' perceptions about the sporting events to include balanced proportions of male and female respondents since spectators' perceptions about the sporting events tend to vary according to gender .This study falls short on this requirement since its sample was heavily tilted in favour of male respondents. However, the dominance of male respondents closely mirrors the football consumption patterns on the Zimbabwean market where there are more male consumers of football products than females.
As a result, the gender bias of the sample had negligible effects on the quality of the findings. Despite this limitation, the research objectives were met.

\section{ACKNOWLEDGMENT}

I wish to thank Professor David Stotlar whose scholarly guidance made it possible for me to complete this study.

\section{REFERENCES}

Aaker, D. A. (1991) Managing brand equity: Capitalizing on the value of a brand name. New York: The Free Press.

Aaker, D. A. (1996) Measuring brand equity across products and markets. California Management Review, 38(3) pp. 102-120.

Aaker, D.A. and Joachimsthaler, E. (2000), Brand Leadership. New York: Free Press.

Andreff, W and Staudohar, P.D. (2002), European and USA Sports Business Models. In: Barros, C.P., Ibrahmo, M and Szymaski, S. (eds.), Transatlantic Sport: The comparative economics of North American and European Sports, Great Britain: Biddle Ltd, pp. 23-49.

Arai, A., Ko, Y.J. and Kaplanidou, K. (2013) Athlete brand image: scale development and model test. European Sport Management Quarterly, 13 (4), pp. 383-403.

Bauer, H. H., Sauer, N. E. and Schmit T, P. (2005) Customer-based brand equity in the team sport industry: Operationalization and impact on the economic success of sport teams. European Journal of Marketing, 39(5/6), pp. 496-515.

Bauer, H.H., Stokburger-Sauer, N.E. and Exler, S. (2008) Brand image and fan loyalty in professional team sport: A refined model and empirical assessment. Journal of Sport, 22, pp. 205226.

Bodet, G and Chanavat, N. (2010) Building global football brand equity: Lessons from the Chinese market.Asia Pacific Journal of Marketing and Logistics, .22 (1), pp. 55-66.

Chanavat, N. and and Bodet, G. (2009) Internationalisation and Sport Branding Strategy: A French Perception of the Big Four Brands, Qualitative Market Research: an International Journal, 12(4), pp. 460-481.

Charumbira, L.T. (2013) The Philosophical and Methodological Approaches Used by Sport and Business Management Student Researchers in Zimbabwe. Global Journal of Commerce and Management Perspective, 2(6), pp.51-56.

Charumbira, L.T. (2014) Strategic Management in Zimbabwean Profit and Non-profit Organizations: Identifying the Missing Tools in the Strategy Implementation Kit Bag.Asian Business Review, 4 (3) pp.7-13.

Charumbira, L.T. (2014) The Perceived Brand Equity of the 2013 Zimbabwe Universities Sports Association Games. Global Journal of Commerce and Management Perspective, 3 (1), pp.82-9.

Charumbira, L.T. (2014), 'The Effectiveness of the Sports Marketing Strategies Used by Zimbabwean Collegiate Sports Federations'. International Journal of Marketing and Business Communication. vol.3, number 3/4 . pp. 66-75.

Charumbira, L.T. and Charumbira, J. (2015) The Use of Sports Sponsorship as a Brand Equity Building Tool by Zimbabwean Companies. Global Journal of Commerce and Management Perspective, 4(4) pp.19-25.

Collins, K. M.T. and Onwuegbuzie, A. J. (2007) A Typology of Mixed Methods Sampling Designs in Social Science Research.The Qualitative Report, 12(2), pp.281-316.

Couvelaere, V. and Richelieu, A. (2005) Brand strategy in professional sports: The case of four French soccer teams. European Sport Management Quarterly, 5(1), pp.23-46.

Creswell, J. W. and Plano Clark, V. L. (2011) Designing and conducting mixed methods research, 2nd Ed. Thousand Oaks, CA: Sage. 
Dall'Olmo Riley, F. (2009) Editor's introduction: brand management. In: Dall'Olmo Riley, F. (ed.), Brand management. London: Sage Publications.

Deloitte (2013), Football Money League. Sport Business Group. United Kingdom: Deloitte LLP.

Deloitte (2014), Football Money League. Sport Business Group. United Kingdom: Deloitte LLP.

Deloitte (2015), Football Money League. Sport Business Group. United Kingdom: Deloitte LLP.

Desbordes, M. (2007) Introduction: new directions for marketing in football. In Desbordes, M. (ed.) Marketing and Football: An International Perspective. Oxford: Butterworth-Heinemann.

Dolles, H. and Solderman, S. (2008),Mega-sporting events in Asiaimpacts on society, business and management: an introduction. Asian Business and Management, 7, pp. 147-62.

Erdem, T. and Swait, J. (2004) Brand Credibility, Brand Consideration, and Choice. Journal of Consumer Research, 31(1) pp.191-198.

Gladden, J.; Milne, GR. and Sutton, W. (1998) A Conceptual Framework for Assessing Brand Equity in Division I Athletics.Journal of Sports Management, 12(1), pp. 1-19.

Gladden, J.M. and Funk, D.C. (2002) Developing an understanding of brand associations in team Sport: Empirical evidence from consumers of professional sport. Journal of Sport Management, 16, pp 54-81.

Gladden, J.M. and Milne, G.R. (1999) Examining the Importance of Brand Equity in Professional Sport. Sports Marketing Quarterly 8(1), pp.54-81.

Griffin, A. and Hauser, J.R. (1992) Patterns of Communication among Marketing, Engineering, and Manufacturing- A Comparison between Two New Product Teams. Management Science, 38, pp. 360-373.

Guest, G., Bunce, A. And Johnson, L. (2006) How many interviews are enough? , 52 (2), pp.224-235.

Higgins. A. (2006) Brand Equity and College Athletics: Investigating the Effects of Brand Uncertainty Situations on Consumer-based Brand Equity. Dissertation Presented in Partial Fulfilment for the Degree Doctor of Philosophy in the Graduate School of The Ohio State. USA: Ohio State University.

Kaynak, E., Salman, G. G. and Tatoglu, E. (2008) An integrative framework linking brand associations and brand loyalty in Professional sports.Journal of Brand Management, 15, 336-357.

Keller, K. L. (1993), 'Conceptualizing, Measuring, and Managing Customer-Based Brand Equity'.Journal of Marketing, .57(1), pp.1-22.

Keller, K.L. (1998) Strategic brand management: Building, Measuring, and Managing Brand Equity. Upper Saddle River, NJ: Prentice Hall.

Keller, K.L. (2001) Building Customer-based Brand Equity. Marketing Journal of Consumer Research Management, 10(2), pp.14-19.

Keller, K.L. (2003) Brand Synthesis: The multidimensionality of brand knowledge. Journal of Consumer Research.29, March., pp.595-600.

Keller, K.L. (2006) Branding and Brand Equity. In: Weitz, B. and Wensley, R. (eds.), Handbook of Marketing, London: Sage Publications.

Keller, K.L. (2008) Strategic Brand Management, 3rd Ed. Upper Saddle River: Pearson Prentice Hall.

Keller, K.L. and Lehmann, D.R. (2003) How Do Brands Create Value?' Marketing Management, 12, May/June, pp.26-31.

Keller, K.L. and Lehmann, D.R. (2006) Brands and Branding: Research Findingsand Future Priorities. Marketing Science, 25(6), pp. 740-759.

Kerr, A. and Gladden, J. M. (2008) Extending the understanding of professional team brand equity to the global marketplace.
International Journal of Sport Management and Marketing, 3(1/2.)Pp.58-77.

Kotler, P. Pfoertsch, W (2006) B2B brand management, Berlin, Springer.

Kunkel, T., Funk, D. and King, C. (2014) Developing a Conceptual Understanding of Consumer-Based League Brand Associations. Journal of Sports Management, 28 (1), pp.49-67.

Langford, B.E., Schoenfeld, G. and Izzo, G. (2002) nominalgrouping sessions versus focus groups. Qualitative Market Research., 5, pp.58-70. Madeiro, G. (2007) Sports and Power: Globalisation and Merchandising on the Soccer World. Society and Business Review, 2(3), pp.287-298.

Naik, A.Y. and Gupta, A. (2013) Illuminating Viewer-Based Brand Equity in Sports, International Journal of Engineering and Management Sciences ,4(2) ,pp.160-172.

Neale, L.G. (2007) Toward a Better Understanding of Uncommon Loyalty: An Application in Sport. Thesis presented for the degree of Doctor of Philosophy (Marketing) at the University of Western Australia, School of Economics and Commerce, Australia: University of Western Australia.

Neuman, L. W. (2003) Social research methods: Qualitative and quantitative approaches 5th Ed. Boston: Allyn and Bacon.

Neuman, L.W. (2004) Basics of Social Research: Qualitative and quantitative approaches: Boston: Pearson Education.

Neumeier, M. (2003) The brand gap: How to bridge the distance between business strategy and design. Berkeley, CA: New Riders.

Onwuegbuzie, A. J. and Teddlie, C. (2003) A framework for analysing data in mixed methods research. In: Tashakkori, A. and Teddlie, C. (eds.), Handbook of mixed methods in social and behavioural research, Thousand Oaks, CA: Sage, pp.351-383.

Onwuegbuzie, A. J., Dickinson, W. B., Leech, N. L. and Zoran, A. G. (2009) A qualitative framework for collecting and analyzing data in focus group research. International Journal of qualitative Methods, .8(3), pp.1-21.

Onwuegbuzie, A.J and Collins, K.M. (2007) A Typology of Mixed Methods Sampling Designs in Social Science Research. The Qualitative Report, 2(2), pp.281-316.

Ries, A. and Ries, L. (1998) The 22 Immutable Laws of Branding: How to build a product or service into a world-class brand. New York: HarperCollins.

Ross, S. (2006) A conceptual framework for understanding spectator-based brand equity. Journal of Sport Management, 20(1), pp. 22-38.

Ross, S., James, J. and Vargas, P. (2006) Development of a scale to measure team brand associations in professional sport. Journal of Sport Management, 20 (2) pp. 260-279.

Ross, S., Russell, K. and Bang, H. (2008) An empirical assessment of spectator-based brand equity.Journal of Sport Management, 22(3), pp.322-337.

Ross, S., Walsh, P. and Maxwell, H. (2009) The impact of team identification on ice hockey brand associations. International Journal of Sport Management and Marketing, 5 (1/2), pp. 196-210.

Trail, G., Fink, J. and Anderson, D. (2002) Environmental factors associated with spectator attendance and sport consumption behaviour: Gender and team differences. Sport Marketing quarterly. 11 (1), pp.8-19.

Wann, D.L., Tucker, K.B. and Schrader, M.P. (1996) An exploratory examination of the factors influencing the origination, continuation, and cessation of identification with sports.

Winters, L.C. (1991) Brand Equity Measures: Some Recent Advances'.Marketing Research, 3 (4), pp.70-73.

Wright, G. (1999) The Impact of Globalization. New Political Economy. 4(2), pp124-141.

$--0--$ 